\title{
ALKALI-RESISTANT HAEMOGLOBIN IN NORMAL GREEK CHILDREN
}

\author{
BY \\ C. CHOREMIS, L. ZANNOS, AND C. DENDAKI \\ From the Paediatric Clinic, Athens University
}

(RECEIVED FOR PUBLICATION JANUARY 20, 1954)

The time of disappearance of embryonic haemoglobin in post-natal life has not yet been definitely determined.

Since Körber in 1866, Krüger in 1888 , and later Bischoff (1926) and Haurowitz $(1929,1930)$ demonstrated the existence of a difference between the resistance of foetal and adult haemoglobin to the denaturing action of alkali, the former being much more resistant than the latter, few papers on this subject have appeared in the literature.

Using electrophoretic and spectroscopic methods Beaven, Hoch, and Holiday (1951) demonstrated that the substitution of foetal haemoglobin by the adult pigment starts during intra-uterine life. The youngest embryo examined was 20 weeks old, and $6 \%$ of its haemoglobin was found to be of the adult type. These authors found that at birth the adult pigment usually amounts to about $20 \%$, which agrees with the previous findings of Haurowitz, while between the third and fourth month about $90 \%$ of foetal haemoglobin has been replaced by adult haemoglobin. This is easily explained by the fact that embryonic red cells are still in the blood stream, the life span of erythrocytes having been estimated to be 120 days. Yet embryonic pigment is still present in small amounts beyond this age, a fact which suggests its post-natal production. The time limit for its disappearance was believed until recently to be the seventh month of life.

Chernoff and Singer (1952) demonstrated that foetal haemoglobin could be found up to the fifth year of life in amounts of $3.1 \%$. This discrepancy with the older literature Singer attributed to his more sensitive method (Singer, Chernoff, and Singer 1951). Instead of measuring the time needed for denaturation of haemoglobin with alkali, Singer determined the percentage of haemoglobin denatured within one minute and stated that very small amounts of resistant pigment-up to $1.7 \%$ - can still be demonstrated in normal adults.

Greater amounts of foetal haemoglobin are encountered as a rule, and independently of age, in sickle cell anaemia and in Cooley's anaemia (Singer et al., 1951; Bianco, 1948; Zannos, 1952). As these diseases are frequent in Greece, we thought it would be interesting to find the age limits at which foetal haemoglobin has completely disappeared from the blood of Greek children. The problem is also of practical interest, since the method of haemoglobin alkali denaturation serves as a diagnostic method for distinguishing the congenital from acquired types of anaemia.

\section{Material and Method}

The present paper deals with the determination of alkali-resistant haemoglobin in 500 Greek children aged between 2 and 7 years. Three hundred and fifty of these children were patients at the paediatric clinic of Athens University, and suffered from diseases which do not affect the haemopoietic system. The remaining were healthy nursery and school children.

Singer's (1951) method was used.

\section{Results and Discussion}

As shown in Table I, foetal haemoglobin is stil! present in a very small percentage of children up to the seventh year of life. The amount is relatively high during the third year, $1.9=6.9 \%$, decreasing gradually to $2=2.6 \%$ during the seventh year. Investigation for blood disease or sickle cell trait or thalassaemia in the cases with foetal pigment yielded negative results.

TABLE I

PERCENTAGE OF FOETAL HAEMOGLOBIN AT DIFFERENT AGES

\begin{tabular}{c|c|c|c}
\hline $\begin{array}{c}\text { Age } \\
\text { in } \\
\text { Years }\end{array}$ & $\begin{array}{c}\text { No. of } \\
\text { Specimens } \\
\text { Examined }\end{array}$ & $\begin{array}{c}\text { No. of } \\
\text { Specimens with } \\
\text { Foetal Hb }\end{array}$ & $\begin{array}{c}\text { Percentage } \\
\text { Foetal } \\
\text { Hb }\end{array}$ \\
\hline $2-3$ & 100 & 23 & $2-6 \cdot 9$ \\
$3-4$ & 100 & 11 & $2-5 \cdot 5$ \\
$4-5$ & 100 & 10 & $2-5 \cdot 1$ \\
$5-6$ & 100 & 8 & $2-4 \cdot 5$ \\
$6-7$ & 100 & 2 & $2-2 \cdot 6$ \\
\hline
\end{tabular}


Comparison of our results with those of Chernoff and Singer shows a slight difference in the age limit of disappearance (seventh instead of the fifth year) as well as in the percentage of foetal haemoglobin, but we do not think that this difference is statistically significant, given the relatively small number of Singer's cases.

It is hoped that the present investigation will stimulate similar studies in other parts of the world, so that further comparisons would be made possible.
REFERENCES

Beaven, G. H., Hoch, H., and Holiday, E. R. (1951). Biochem. J., $49,374$.

Bianco, I. (1948). Policlinico Sez. Prat., 55, 103.

Bischoff, H. Z. (1926). Z. Ges. exp. Med., 48, 472.

Chernoff, I. A., and Singer, K. (1952). Pediatrics, 9, 469

Haurowitz, F. Z. (1929). Hoppe-Seyl. Z. physiol. Chem., 183, 78.

Körber, F. (1866). 186, 141. Utber Differenzen des Blutfarbstoffs. Thesis, Dorpat. Cited in Hematin Compounds and Bile Pigments, p. 308, by $R$. Lemberg and J. W. Legge. Interscience Publishers, New York, 1949.

Krüger, F. (1888). Z. Biol., 24, 318.

Singer, K., Chernoff, 1. A., and Singer, L. (1951). Blood, 6, 413.

Zannos, (1952). Thesis submitted to the Medical School of Athens University. 